Revista de Matemática: Teoría y Aplicaciones 2009 16(2): 255-266

CIMPA - UCR ISSN: 1409-2433

\title{
EVALUATION OF AIR POLLUTION CONTROL POLICIES IN MEXICO CITY USING FINITE MARKOV CHAIN OBSERVATION MODEL
}

\author{
Luis Hoyos* Pedro LarA $^{\dagger} \quad$ Elba ORTiz P $^{\ddagger} \quad$ RAFAel LóPez $^{\S}$ \\ Jesús GonZÁLEz
}

Recibido/Received: 20 Feb 2008 - Aceptado/Accepted: 1 Dic 2008

\begin{abstract}
This paper proposes a Markov observation based model, where the transition matrix is formulated using air quality monitoring data for specific pollutant emissions, with the primary objective to analyze the corresponding stationary distributions and evaluate sceneries for the air quality impact of pollution control policies. The model is non predictive and could be applied to every source of pollutant emissions included in air monitoring data. Two cases of study are presented, ozone and sulfur, over central zone of Mexico City for a seven years span from 2000 to 2006. For presentation purposes each year were divided in two semesters. In ozone case, the stationary distribution for both semesters shows a probability diminution of the higher ozone concentrate levels, with tendency to "piston effect". In the sulfur case, the first semester displays an oscillatory behavior with a little tendency to diminution of the higher sulfur concentrate levels, the second semester had decreasing probabilities of the higher sulfur levels. The results support an small improvement of air quality and then a favorable evaluation of the diverse pollution control policies that had been implemented in Mexico City over the last several years.
\end{abstract}

Keywords: Markov chain, stationary distribution, air pollution, sulfur emissions, ozone emissions, Mexico City.

\footnotetext{
*Departamento de Sistemas, Universidad Autónoma Metropolitana Azcapotzalco, Av. San Pablo 180, Col. Reynosa Tamaulipas, C.P. 02200, México, D. F., México. E-Mail: hrlf@correo.azc.uam.mx

${ }^{\dagger}$ Departamento de Sistemas, misma dirección que Hoyos. E-Mail: pedro_lara@correo.azc.uam.mx

${ }^{\ddagger}$ Departamento de Ciencias Básicas, misma dirección que Hoyos. E-Mail: meorv@correo.azc.uam.mx

${ }^{\S}$ Departamento de Sistemas, misma dirección que Hoyos. E-Mail: rlb@correo.azc.uam.mx

『Departamento de Sistemas, misma dirección que Hoyos. E-Mail: gtji@correo.azc.uam.mx
} 
256 L.Hoyos - P.LARA - E.OrTIZ - R.LÓPEZ - J.GonZÁLEZ Rev.Mate.Teor.Aplic. (2009) 16(2)

\section{Resumen}

En este trabajo se propone un modelo de Markov basado en observaciones, donde la matriz de transición se formula empleando información del monitoreo de la calidad del aire para ciertos contaminantes específicos, con el objetivo principal de analizar las distribuciones estacionarias correspondientes y evaluar escenarios del impacto de las medidas de control anticontaminantes de la calidad del aire. El modelo no es predictivo y puede aplicarse a cualquier fuente de emisiones contaminantes incluidas en el sistema de monitoreo ambiental. Se presentan dos casos de estudio, ozono y azufre, sobre la zona central de la Ciudad de México para un intervalo de siete años del 2000 al 2006. Para propósitos de presentación, cada año se dividió en dos semestres. En el caso del ozono, la distribución estacionaria para ambos semestres mostró una disminución en la probabilidad de ocurrencia de los niveles de alta concentración de ozono, con cierta tendencia al "efecto pistón". En el caso del azufre, el primer semestre mostró un comportamiento oscilatorio con una pequeña tendencia a la disminución de los niveles de alta concentración y en el segundo semestre disminuyeron las probabilidades de altos niveles de azufre. Los resultados establecen una ligera mejoría en la calidad del aire y por lo tanto una evaluación favorable de las diversas medidas de control de contaminantes que han sido implementadas en la Ciudad de México en los últimos años.

Palabras clave: Cadenas de Markov; distribución estacionaria; contaminación del aire; emisiones de azufre; emisiones de ozono; Ciudad de México.

Mathematics Subject Classification: 60J20, 91B76.

\section{Introduction}

Urban air pollution is a major environmental problem. High ozone and sulfur concentrations in Mexico City have limited severely its air quality for at least 15 years [6]. The increasing of urbanization as demographic trend, has important direct and indirect impacts in atmospheric pollution. The facts of its elevation of $2.2 \mathrm{~km}$ above sea level surrounded by mountains and its tropical location $\left(\right.$ at $\left.19^{\circ} \mathrm{N}\right)$ contributes to the problem.

Diverse dispersion models $[2,4,6,11]$ had been formulated for the evolution, prediction and impact of pollutants in particular for ozone $\left(\mathrm{O}_{3}\right)$ and sulfur dioxide $\left(\mathrm{SO}_{2}\right)$. The proposed Markov model is an observation based model so it could be formulated to every pollutant allowing a systematic protocol analysis for each specified pollutant. This is an advantage from already studied techniques based on emissions estimation and inventories development [4], photochemical models [11] and Eulerian turbulent diffusion [6], that were developed for a particular pollutant only.

In the last 15 years air pollution control policies had been implemented [7]. Up to date, there is not a consensus on the procedure to evaluate the impact or efficiency of the air pollution control policies [10]. The main objective of this work is to formulate an stochastic model based in Markov chains to evaluate the impact of this policies in the concentration of air pollutants, in particular ozone and sulfur models for central zone of Mexico City are presented. Software Matlab was used to compute numerical results. 


\section{Markov model formulation}

In general terms, a Markov model is an stochastic process where the evolution of the system for the next moment depends only of the last moment [9]. The hypothesis of Markovian behavior [1] is associated with the continuity of the pollutant concentration dynamics. In other words, the concentration level at moment $k+1$ depends of the concentration level at moment $k$, considering short enough time intervals.

Definition 2.1 Let $M$ be the probabilities matrix associated to the time series sample of the specific pollutant concentration levels, where each state from $\{1,2, \ldots, n\}$ represents a concentration interval, with 1 for the lowest level and $n$ for the highest concentration. So each entry $m_{i j}$ of $M$ is the transition probability from state $i$ to state $j$ in a time interval of length 1 (predefined unit of time).

Definition 2.2 The collection $\left\{X_{n}, n \geq 0\right\}$ of random variables is called concentration levels Markov chain $(\boldsymbol{C M C})$, where $X_{i}$ is the concentration level at moment $i$ and $M$ is the probability matrix associated $(\boldsymbol{P} \boldsymbol{M})$.

Definition 2.3 A probabilities matrix is regular if there exists $r \in \mathbb{N}$, so $M^{r}$ have only components strictly positive.

$M^{r}$ is the CMC for $r$ units of time in the future under fixed system conditions.

If the Markov chain is regular, then stationary distribution $\Pi=\left(\pi_{1}, \pi_{2}, \ldots, \pi_{n}\right)$ always exist [9], where $\pi_{i}$ is the probability to be in state $i$ after a very long time, that is, the following limit exist

$$
\Pi=\lim _{k \rightarrow \infty} p_{0} M^{k}
$$

and $p_{0}$ is the pollutant concentration level initial distribution.

Conditions of the analyzed system could change year by year or month by month, because of variations in industrial activities, growth of old and poorly maintained car fleet or meteorological phenomena. To avoid the technical difficulties inherent to a non stationary process, it is necessary to construct different $P M M_{0}, M_{1}, \ldots, M_{k}$, for each time interval and compute the associated stationary distributions $\Pi_{0}, \Pi_{1}, \ldots, \Pi_{k} . M_{0}$ is an estimated realization of the non-stationary transition probabilities under the observational data from time interval $\left[t_{0}, t_{0}+1\right]$. The associated stationary distribution $\Pi_{0}$ could be interpreted as the vector of probabilities for each pollutant concentration level for a very long time from now, if system conditions do not change.

Comparison between $\Pi_{0}$ and $\Pi_{k}$ leads to conclude if the air pollution control policies had been or not successfully implemented moreover, it is possible to determine if the policies converge to asymptotic behavior, so the limit of its efficiency is held.

An important remark is that the model strongly depends of the observational data and the formulation and analysis do not require additional hypothesis or modifications for any specific pollutant. The classification of the air quality according according SIMAT [8], Sistema de Monitoreo Atmosférico (Atmospheric Monitoring System) is presented in Table 1. 
258 L.Hoyos - P.LARA - E.OrTIZ - R.LÓPEZ - J.GonZÁLEZ Rev.Mate.Teor.Aplic. (2009) 16(2)

\begin{tabular}{c|l}
\hline \hline Range IMECA & Air quality \\
\hline$[0,100]$ & Satisfactory \\
$(100,200]$ & Not satisfactory condition \\
$(200,300]$ & Bad air quality \\
{$[300,500]$} & Very bad condition \\
\hline \hline
\end{tabular}

Table 1: Classification of the air quality according SIMAT.

\section{Ozone case in central zone of Mexico City}

In January of 1991 it was implemented the program Hoy no circula (unavailable for use today) with the main objective of improve the air quality [7], also cleaner gasolines had been introduced with the same objective [2]. Accordingly with Distrito Federal (Federal District) government [8], the qualitative classification of the pollutants concentration levels in Indice Metropolitano de la Calidad del Aire IMECA (Metropolitan Index of Air Quality) units is reported in Table 1. In the ozone specific case, the contingency policies are activated when the concentration are above 240 IMECA units and deactivated when the concentration is below 180 IMECA units [8]. In the last years the precontingency and contingency were seldom activated, but do not means that the control policies had improved air quality [12].

The model was applied to analyze ozone concentration for seven years, from 2000 to 2006, considering observational data from three stations of the RAMA, Red Automática de Monitoreo Ambiental (Automatic Network for Environmental Monitoring): Lagunilla, Merced and Hangares. These stations were selected on the basis of its data confidence and high demographic density environment. The geographical location of each station is shown in Figure 1.

\begin{tabular}{c|c}
\hline \hline State & Range IMECA \\
\hline 1 & {$[0,25)$} \\
2 & {$[25,50)$} \\
3 & {$[50,75)$} \\
4 & {$[75,100)$} \\
5 & {$[100,125)$} \\
6 & {$[125,500]$} \\
\hline \hline
\end{tabular}

Table 2: Definition of the ozone states.

Under the observation based method (OBM) $[3,5]$, the time series of the ozone concentrations reveals dynamics between 10:00 and 18:00 hrs. The samples were taken every 2 hours with periodic boundary conditions, during a six months period, but the periods 


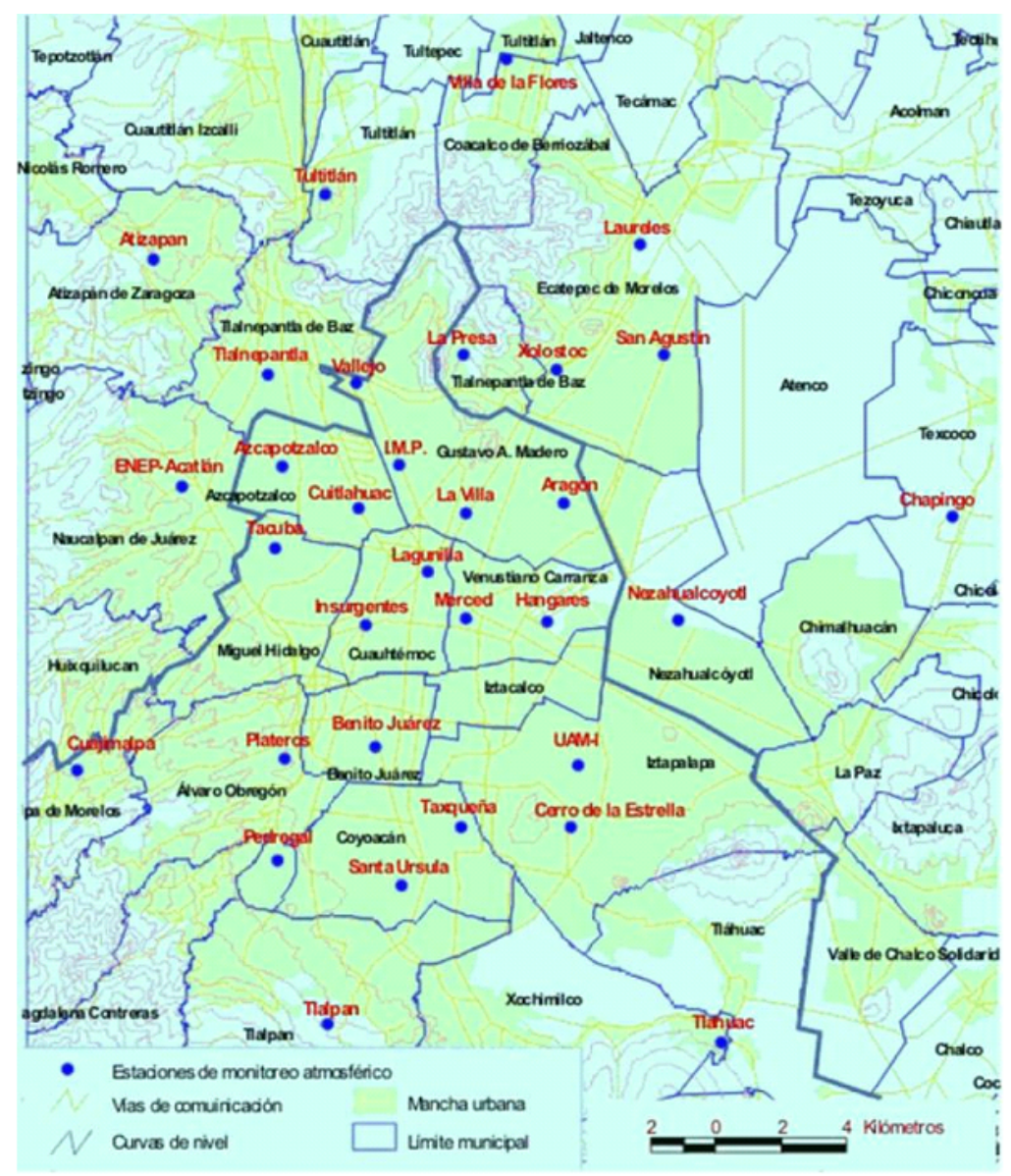

Figure 1: RAMA stations distribution in Mexico City Metropolitan Area.

could be any finite time interval. The six states of the CMC where defined as is reported in Table 2.

For the first semester of the years $2000,2001, \ldots, 2006$, the corresponding PM $M_{00}^{1}, M_{01}^{1}$, $\ldots, M_{06}^{1}$ were computed using the OBM. For example, the PM for year 2000 is:

$$
M_{00}^{1}=\left[\begin{array}{llllll}
0.649497 & 0.106784 & 0.131910 & 0.087940 & 0.023869 & 0.000000 \\
0.115299 & 0.272728 & 0.172949 & 0.246120 & 0.152993 & 0.039911 \\
0.070560 & 0.250608 & 0.294404 & 0.199513 & 0.124088 & 0.060827 \\
0.028302 & 0.165094 & 0.242925 & 0.261792 & 0.162736 & 0.139151 \\
0.014652 & 0.106227 & 0.227106 & 0.278389 & 0.179487 & 0.194139 \\
0.016854 & 0.061798 & 0.191011 & 0.219101 & 0.286517 & 0.224719
\end{array}\right]
$$


260 L.Hoyos - P.LARA - E.OrTIZ - R.LÓPEZ - J.GonZÁLEZ Rev.Mate.Teor.Aplic. (2009) 16(2)

The stationary distributions for the first semester are reported in Table 3.

\begin{tabular}{c|cccccc}
\hline \hline Year & $\pi_{1}$ & $\pi_{2}$ & $\pi_{3}$ & $\pi_{4}$ & $\pi_{5}$ & $\pi_{6}$ \\
\hline 2000 & 0.131045 & 0.175659 & 0.219660 & 0.220648 & 0.149637 & 0.103351 \\
2001 & 0.191339 & 0.237164 & 0.240796 & 0.168503 & 0.106028 & 0.056170 \\
2002 & 0.148855 & 0.230111 & 0.261134 & 0.190956 & 0.110309 & 0.058635 \\
2003 & 0.172601 & 0.239293 & 0.261264 & 0.184314 & 0.095860 & 0.046668 \\
2004 & 0.311737 & 0.288010 & 0.220813 & 0.121069 & 0.041432 & 0.016938 \\
2005 & 0.195416 & 0.221050 & 0.312795 & 0.211375 & 0.092191 & 0.040259 \\
2006 & 0.139360 & 0.265620 & 0.312795 & 0.201122 & 0.066974 & 0.014127 \\
\hline \hline
\end{tabular}

Table 3: $O_{3}$ stationary distributions for the first semester.

Sates five and six constitutes the worst environmental conditions, therefore, a meticulous analysis of its behavior must be done. The dynamic evolution of states five and six is displayed in Figure 2.

The probability that ozone concentration were between 100 and 125 IMECA units, corresponding to state five, had diminished $55.24 \%$ since year 2000 , and the probability to be over 125 IMECA units had diminished $86.33 \%$.

The same method was applied for the second semester of each year, first computing $M_{00}^{2}$, $M_{01}^{2}, \ldots, M_{06}^{2}$ and then the stationary distributions, which are reported in Table 4.

\begin{tabular}{c|cccccc}
\hline \hline Year & $\pi_{1}$ & $\pi_{2}$ & $\pi_{3}$ & $\pi_{4}$ & $\pi_{5}$ & $\pi_{6}$ \\
\hline 2000 & 0.164827 & 0.252757 & 0.240928 & 0.176730 & 0.096668 & 0.068090 \\
2001 & 0.217547 & 0.284507 & 0.233448 & 0.159799 & 0.067448 & 0.037251 \\
2002 & 0.231255 & 0.283111 & 0.221690 & 0.169697 & 0.070789 & 0.023460 \\
2003 & 0.229383 & 0.276506 & 0.269214 & 0.140256 & 0.065042 & 0.019599 \\
2004 & 0.214117 & 0.280281 & 0.289081 & 0.152426 & 0.050273 & 0.013822 \\
2005 & 0.211798 & 0.354309 & 0.261339 & 0.118052 & 0.047045 & 0.007457 \\
2006 & 0.351209 & 0.280145 & 0.260652 & 0.084838 & 0.018704 & 0.004452 \\
\hline \hline
\end{tabular}

Table 4: $\mathrm{O}_{3}$ stationary distributions for the second semester.

In Figure 3, states five and six had decreasing probability occurrence, with a decrease of $80.65 \%$ for state 5 and $93.46 \%$ for the state with largest ozone concentration level.

It seems like the policies had been successfully implemented, but only the largest concentration levels decrease, something analog to the piston effect [12], with control policies with fast and early drop impact, which tends to disappear, and states two and three that actually increments its probability of occurrence, a deviation from the objective to converge to the optimum stationary distribution $(1,0,0,0,0,0)$.

Qualitative comparisons with the Environment Protection Agency (EPA) 8 hour standard over the same six years span had been made and will be matter for later reports. These analyses are consistent with the presented results.

The two largest probabilities for 2006 first semester stationary distribution are $\Pi_{2}$ and $\Pi_{3}$, 


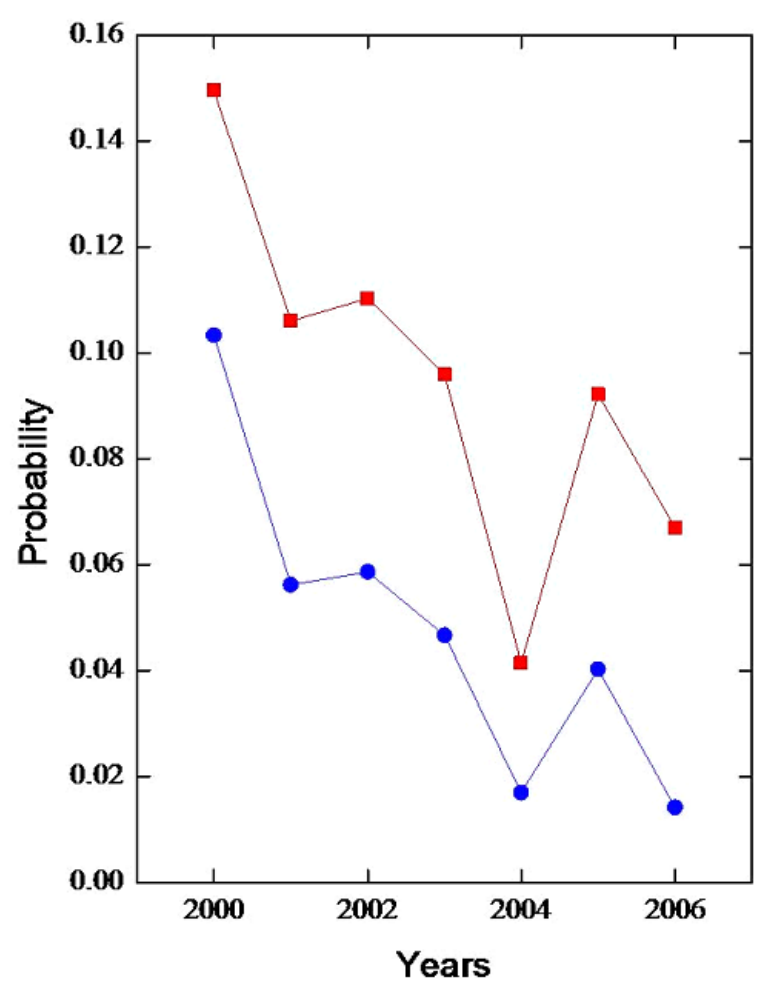

Figure 2: Evolution of state five (blue squares) and state six (red circles).

whereas $\Pi_{1}$ and $\Pi_{2}$ are the 2006 second semester largest probabilities. This fact can be explained by taking into account the ozone photochemical non-linear behavior which have been extensively studied in literature [11], given that second semester days are shorter than first semester days.

\section{Sulfur dioxide case in central zone of Mexico City}

The sulfur dioxide had very different dynamics, so the sample had to be taken every 2 hours considering the 24 hour span. In this case, only five states were considered and they are reported in Table 5.

The same methodology applied to analyze ozone behavior was employed to study sulfur dioxide concentrations. Observational data from Lagunilla, Merced and Hangares RAMA stations were employed. Data of years 2000 to 2006 were divided in two semesters. The first and second semester stationary distributions of the seven years are displayed in Tables 
262 L.Hoyos - P.LARA - E.ORTIZ - R.LóPeZ - J.GonZÁlez Rev.Mate.Teor.Aplic. (2009) 16(2)

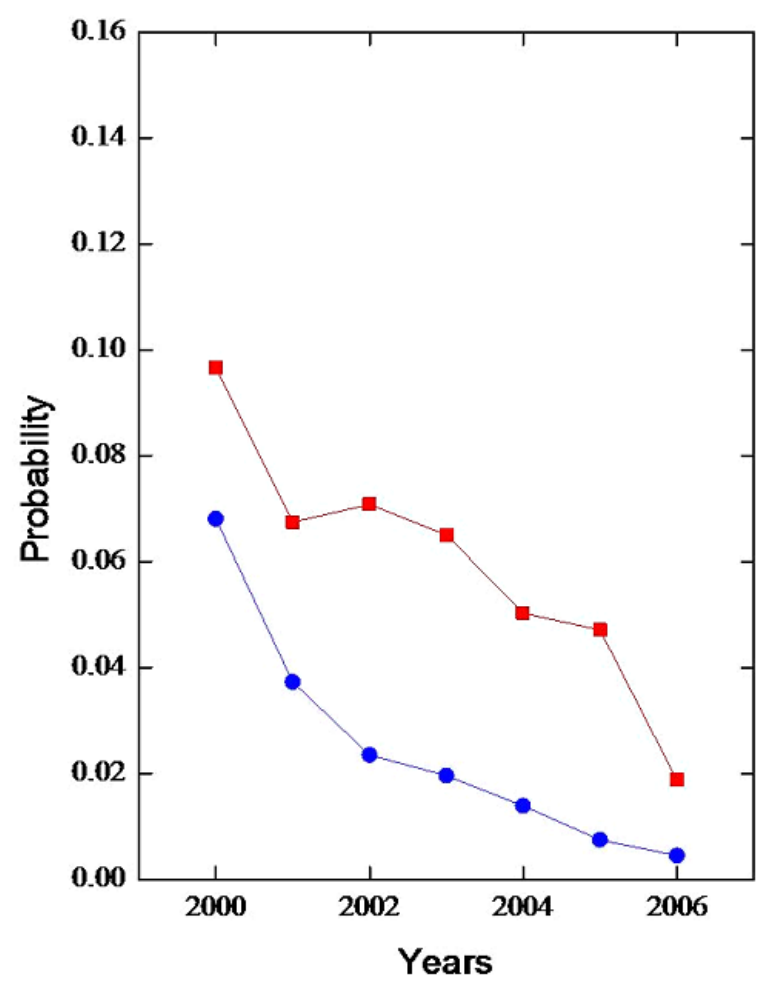

Figure 3: Evolution of state five (blue squares) and state six (red circles).

\begin{tabular}{c|c}
\hline \hline State & Range IMECA \\
\hline 1 & {$[0,20)$} \\
2 & {$[20,40)$} \\
3 & {$[40,60)$} \\
4 & {$[60,80)$} \\
5 & {$[80,500)$} \\
\hline \hline
\end{tabular}

Table 5: Definition of the sulfur states.

6 and 7 respectively.

The dynamic evolution of the worst environmental conditions, states four and five is displayed in Figures 4 and 5, which shows the first and the second semester respectively. In this case, the policies had successfully diminished the sulfur concentration levels, with high and intermediate states probabilities close to zero. Figures 4 and 5 displayed an oscillatory but asymptotic behavior of the pollutant. 


\begin{tabular}{c|ccccc}
\hline \hline Year & $\pi_{1}$ & $\pi_{2}$ & $\pi_{3}$ & $\pi_{4}$ & $\pi_{5}$ \\
\hline 2000 & 0.796931 & 0.164810 & 0.024270 & 0.007151 & 0.006838 \\
2001 & 0.768233 & 0.206104 & 0.021620 & 0.003111 & 0.000932 \\
2002 & 0.836512 & 0.123060 & 0.026019 & 0.009595 & 0.004814 \\
2003 & 0.895802 & 0.078360 & 0.018492 & 0.004523 & 0.002827 \\
2004 & 0.896055 & 0.067126 & 0.023535 & 0.008585 & 0.004699 \\
2005 & 0.893238 & 0.073063 & 0.020113 & 0.008218 & 0.005368 \\
2006 & 0.934501 & 0.048893 & 0.011134 & 0.003466 & 0.002006 \\
\hline \hline
\end{tabular}

Table 6: $\mathrm{SO}_{2}$ stationary distributions for the first semester.

\begin{tabular}{c|ccccc}
\hline \hline Year & $\pi_{1}$ & $\pi_{2}$ & $\pi_{3}$ & $\pi_{4}$ & $\pi_{5}$ \\
\hline 2000 & 0.730648 & 0.218822 & 0.031062 & 0.010864 & 0.008604 \\
2001 & 0.924605 & 0.056446 & 0.009918 & 0.004517 & 0.004514 \\
2002 & 0.909911 & 0.063564 & 0.016867 & 0.006160 & 0.003498 \\
2003 & 0.918607 & 0.059299 & 0.014582 & 0.004120 & 0.003392 \\
2004 & 0.895399 & 0.085830 & 0.013170 & 0.004239 & 0.001362 \\
2005 & 0.905034 & 0.058782 & 0.018485 & 0.010284 & 0.007415 \\
2006 & 0.963426 & 0.028623 & 0.004771 & 0.001817 & 0.001363 \\
\hline \hline
\end{tabular}

Table 7: $\mathrm{SO}_{2}$ stationary distributions for the second semester.

\section{Concluding remarks}

The program Hoy no circula and the introduction of fossil combustibles with low sulfur content had a positive impact in the air quality of central zone of Mexico City, but the control policies success had to be carefully analyzed, the increase of ozone intermediate concentrations, states that new complementary policies had to be implemented.

The sulfur dioxide case is very optimistic. The concentration levels tends to converge to the first state, which implies that almost every day had good air quality.

The formulated Markov model had shown its flexibility to deal with diverse pollutants. It is remarkable that consistency with the ozone photochemical high non-linear behavior was also observed. The analysis for other important pollutants, as well as the extension for non homogeneous finite Markov chain, would be matter of later papers.

\section{References}

[1] Alvarez, L.J.; Fernández-Bremauntz, A.A.; Rodríguez, E.R.; Tzintzun, G. (2005) "Maximum a posteriori estimation of the daily ozone peaks in Mexico City", Journal of Agricultural, Biological \& Environmental Statistics 10: 276-290.

[2] Bravo, H.A.; Torres, R.J. (2000) "The usefulness of air quality monitoring and air quality impact studies before the introduction of reformulated gasolines in developing 
264 L.Hoyos - P.LARA - E.OrTIZ - R.LÓPEZ - J.GonZÁLEZ Rev.Mate.Teor.Aplic. (2009) 16(2)

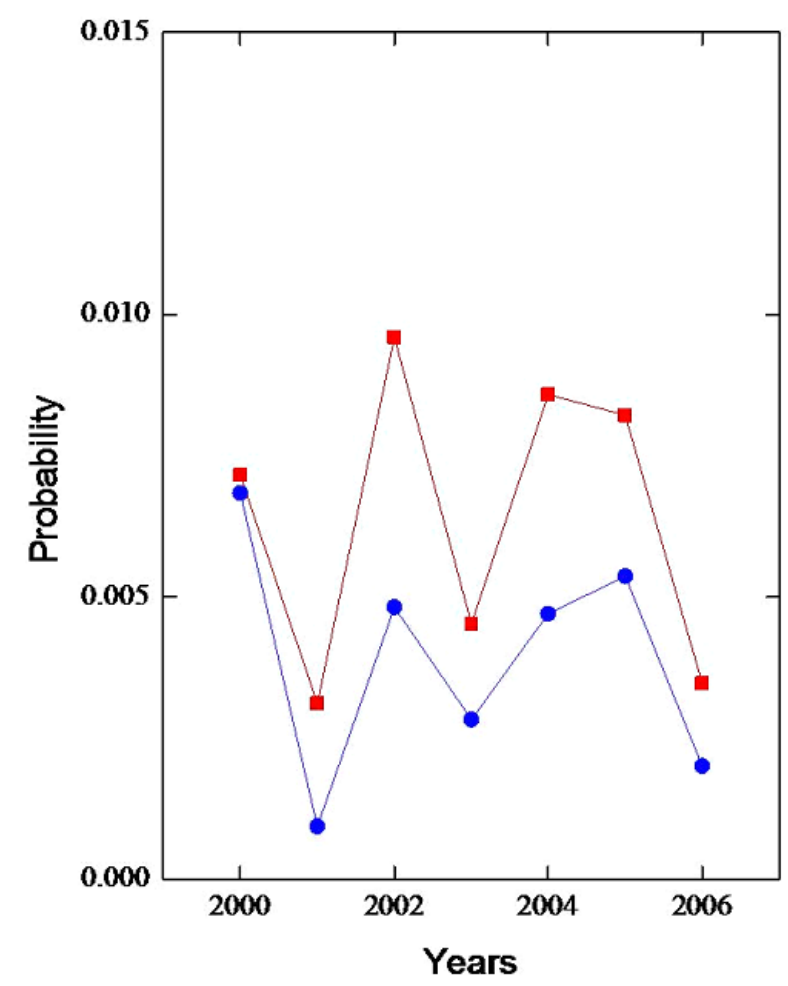

Figure 4: Evolution of state four (blue squares) and state five (red circles).

countries: Mexico City, a real case study", Atmospheric Environment 34: 499-506.

[3] Morris, R.E.; McNally, D.E.; Tesche, T.W.; Tonnesen, G.S.; Boylen, J.W.; Brener, P. (2005) "Preliminary evaluation of the community multiscale air quality model for the 2002 over southeastern United States", Journal of the Air $\&$ Waste Management Association 55: 1694-1708.

[4] Placet, M.; Mann, C.O.; Gilbert, M.J.; Niefer, M.J. (2000) "Emissions of ozone precursors from stationary sources: a critical review", Atmospheric Environment 34: $2183-2204$.

[5] Quin, Y.; Tonnesen, G.S.; Wang, Z. (2004) "One hour and 8-hour average ozone in the California South Coast Air Quality Management District: Trends in peaks values ans sensitivity to precursors", Atmospheric Environment 38: 2197-2207.

[6] Raga, G.B.; Raga, A.C. (2000) "On the formation of an elevated ozone peak in Mexico City", Atmospheric Environment 34: 4097-4102. 


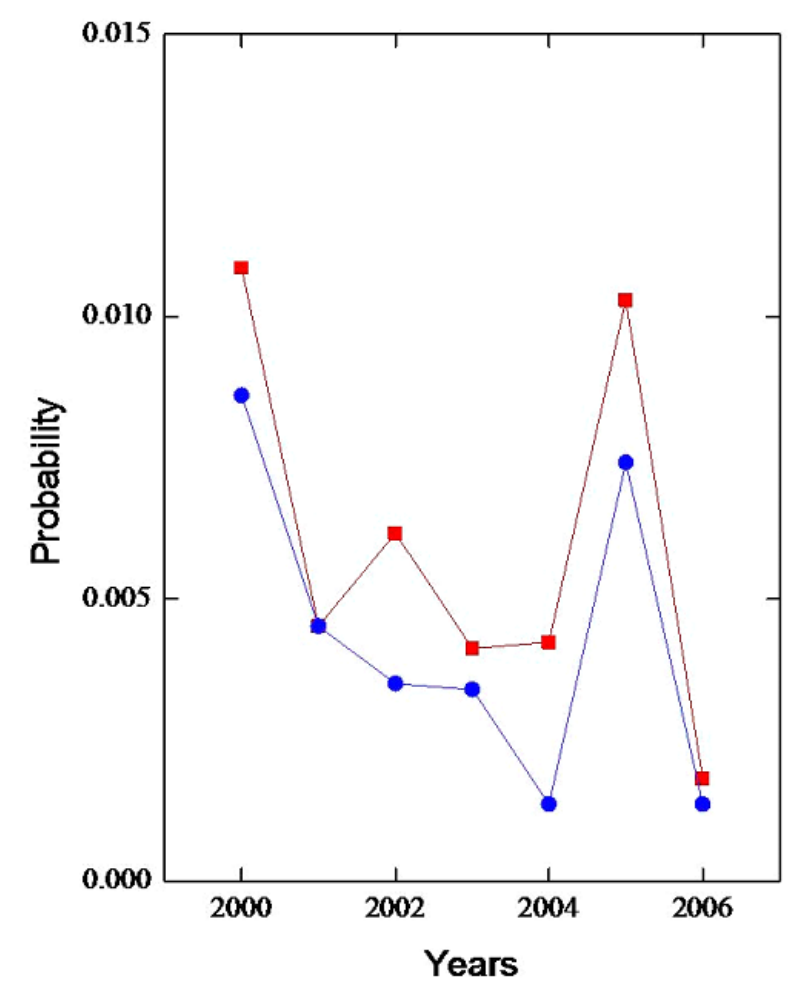

Figure 5: Evolution of state four (blue squares) and state five (red circles).

[7] SMA (2004) Actualización del Programa Hoy No Circula. Gobierno del Distrito Federal, Secretaría del Medio Ambiente, Dirección General de Gestión Ambiental del Aire, México.

[8] SIMAT (2006) Base de Datos del Sistema de Monitoreo Atmosférico de la Ciudad de México. Gobierno del Distrito Federal, Secretaría del Medio Ambiente, Dirección General de Gestión Ambiental del Aire, México. http://www.sma.df .gob.mx/simat/paginabases.htm

[9] Timjs, H. C. (1998) Stochastic Models. An Algorithmic Approach. John Wiley \& Sons, London.

[10] WHO (1997) WHO guidelines for air quality. WHO Information Fact Sheet no. 187. http://www. who.int/inffs/en/fact187.html. 
266 L.Hoyos - P.LARA - E.OrTIZ - R.LóPEZ - J.GonZÁLEZ Rev.Mate.Teor.Aplic. (2009) 16(2)

[11] Zhang, J. (2004) Analyses of Atmospheric Pollutants in Atlanta and Hong Kong using Observation-Based Methods. PhD. Thesis, Georgia Institute of Technology, Atlanta GA.

[12] Ziman, S.; Lefohn, A.S.; Shadwick, D.S.(1998) "Difficult challenge of attaining EPAs new ozone standard", Environmental Science \& Technology, June 1: 276A-282A. 